\title{
Strategi Pemasaran Pertunjukan Jakarta Simfonia Orchestra
}

\author{
Ganang Dwi Asmoro \\ Program Pascasarjana Institut Seni Indonesia \\ Yogyakarta \\ ganang.horn@yahoo.com
}

\begin{abstract}
Abstrak
Keberadaan sebuah kelompok orkestra simfoni membutuhkan beberapa faktor, selain sumber daya manusia yang bagus juga diperlukan strategi pemasaran yang tepat. Posisi pemasaran dalam hal ini bisa disebut sebagai perantara antara kelompok orkestra simfoni dengan penonton dalam melakukan transaksi untuk memuaskan kebutuhan dan keinginan penonton. Karena itu, setiap manajemen orkestra dituntut untuk berpikir kreatif dan strategis untuk menjaga keberlanjutan kelompoknya. Penelitian ini bertujuan menganalisa pemasaran yang dilakukan oleh Jakarta Simfonia Orchestra dengan teknik SWOT dari faktor lingkungan internal dan eksternal yang dihadapi oleh pengelola JSO selama ini. Metode yang digunakan adalah metode kualitatif deskriptif melalui teknik wawancara mendalam terhadap 6 narasumber dan observasi serta didukung dengan data kuantitatif dari survei 100 penonton JSO yang diambil dalam dua pertunjukan. Secara spesifik sebagai studi awal analisis di dalam penelitian ini mendeskripsikan produk, tempat, harga, dan promosi. Hasil dari penelitian ini adalah rekomendasi untuk membuat pertunjukan terjadwal dalam satu tahun, pengelolaan penonton yang berkelanjutan dengan membuat wadah keanggotaan penonton tetap, dan memberikan perhatian lebih kepada penonton dari anggota jemaat, serta membuat program yang menarik dengan sering mendatangkan musisi internasional.
\end{abstract}

Kata kunci: strategi, pemasaran, formulasi, Jakarta simfonia orchestra

\begin{abstract}
The existence of a symphony orchestra groups requires several factor. In addition to good human resources, appropriate marketing strategies are also required. Marketing position in this case can be called as an intermediary between symphony orchestra group and the audience in the transaction to satisfy the need and desires of the audience. Therefore, every orchestra management is required to think creatively and strategically in maintaining the sustainability of its group. This study aims to analisys the marketing conducted by Jakarta Simfonia Orchestra with SWOT technique from internal and external environment factors faced by JSO manager so far. The method used is descriptive qualitative method trhough indepth interview technique to 6 resource person and observation. This study is also suported by quantitatif data from survey $100 \mathrm{JSO}$ audiences taken from two perfomances. As an initial study, the analisys in this study specifically describes the product, place, price, and promotion. The results of this studsy shows that a schedule one-year performance, an ongoing permanent audience membership management, special attention given to the audience of the congregation members, and managing interisting program by involving internasional musicians are recommended as the marketing strategy of the Jakarta Simfonia Orchestra groups.
\end{abstract}

Keywords: strategy, marketing, formulation, Jakarta simfonia orchestra. 


\section{Pendahuluan}

Hampir semua kota besar di dunia pada umumnya memiliki orkestra simfoni, bahkan bagi kota besar yang sudah maju selalu memiliki orkestra simfoni lebih dari satu. Jakarta sebagai ibukota negara di Indonesia, juga memiliki banyak kelompok orkestra simfoni yang didirikan dengan berbagai macam latar belakang, dari orkestra simfoni hasil studi sekolah hingga orkestra profesional yang berorientasi sebagai simbol sebuah kota besar.

Orkes simfoni di Indonesia mengalami masa pasang surut yang panjang. Banyak dari kelompok orkestra simfoni yang didirikan, namun juga banyak orkestra simfoni yang tidak bisa bertahan lama. Kebanyakan dari kelompok orkestra simfoni tersebut muncul di ibukota Jakarta, namun tak dipungkiri bahwa kota-kota besar di Indonesia juga mendirikan orkestra simfoni. Beberapa kelompok orkestra tercatat cukup terkenal diantaranya adalah Batavia Philharmonic Orkestra (1942), Orkes Radio Jakarta (1950), Orkes Studio Jakarta (1950), Orkes Simfoni Jakarta (1978), Nusantara Symphony Orkestra (1988), Twilite Orkestra (1991), Surabaya Symphony Orkestra (1995), Jakarta Chamber Orkestra (2000), Jogjakarta Philharmonic Orcehstra (2004), dan Bandung Philharmonic Orkestra (2014) (Susilo, 2012:6). Sementara itu, di periode tahun 2000-an ada beberapa kelompok orkestra yang didirikan institusi pendidikan seperti Orkes Simfoni Institut Seni Indonesia Yogyakarta dan Mahawaditra dari Universitas Indonesia serta institusi sekolah yang lain juga aktif namun dalam wilayah terbatas.

Keberadaan sebuah kelompok orkestra simfoni dibutuhkan sumber daya yang besar, dari manajemen yang baik, pembiayaan yang berkelanjutan, kualitas musisi yang bagus dan juga strategi pemasaran yang tepat. Pemasaran yang baik dan tepat adalah salah satu faktor yang memiliki peran penting untuk mencapai tujuan yang diinginkan dalam keberlanjutan sebuah kelompok orkestra. Posisi pemasaran dalam hal ini bisa disebut sebagai perantara antara kelompok orkestra simfoni dengan penonton dalam melakukan transaksi untuk memuaskan kebutuhan dan keinginan dari penonton dalam sebuah pertunjukan. Salah satu jenis pemasaran yang populer saat ini adalah strategi bauran pemasaran (marketing mix) 4p yang terdiri dari product, price, place, dan promotion. Menurut Kotler (2000:18) marketing mix merupakan campuran pemasaran yang terdiri dari variabel-variabel pemasaran yang dapat digunakan oleh pemasar perusahaan untuk mengejar tingkat penjualan yang diinginkan dalam pasar sasaran. Banyaknya kelompok orkestra simfoni yang muncul saat ini tentu akan memaksa setiap manajemen orkestra untuk berpikir strategis dalam menjaga keberlanjutan kelompoknya. Salah satu kelompok orkestra yang dimaksud adalah Jakarta Simfonia Orchestra (JSO) yang selalu konsisten untuk menyelenggarakan pertunjukan musik klasik.

Jakarta Simfonia Orchestra didirikan oleh Stephen Tong yang berambisi ingin menyejajarkan Kota Jakarta dengan kota-kota besar dunia yang memiliki kelompok orkestra profesional sebagai simbol dari kemajuan kota. Produk yang ditawarkan oleh kelompok musik ini adalah berupa pertunjukan orkestra simfoni yang memainkan jenis musik klasik. Harga tiket yang tawarkan mulai dari harga Rp 150.000,00 (seratus lima puluh ribu rupiah) untuk kelas pelajar hingga harga Rp 2.000.000,00 (dua juta rupiah) untuk kelas VVIP dalam satu kali pertunjukan. Kelompok ini memiliki home base di aula simfonia Jakarta, sebuah Concert Hall yang juga didirikan oleh Stephen Tong yang terletak di daerah 
Kemayoran, Jakarta. Tempat konser yang menjadi pusat pertunjukan musik klasik di Indonesia inilah, JSO rutin menyelenggarakan pertunjukan orkestra simfoni hampir di setiap bulannya.

Untuk memasarkan pertunjukan ini, pengelola memiliki website aulasimfoniajakarta.com yang dapat memberikan informasi agenda yang akan diselenggarakan oleh JSO. Publikasi di dalam surat kabar kadang kala dilakukan ketika menjelang hari pertunjukan sudah mulai dekat. Mempromosikan agenda pertunjukan dengan media sosial juga dilakukan secara masif dan seringkali juga para anggota musisi aktif dalam memberikan informasi di media sosial meskipun itu atas kesadaran sendiri. JSO didirikan pada tahun 2008 dengan melibatkan para musisi terbaik di Indonesia, serta dirigen senior dari San Diego bernama Dr. Yahya Ling (Harianto, wawancara 3 April 2017). Beberapa nama yang sering menjadi dirigen yang memimpin pertunjukan orkestra ini adalah Rebecca Tong dan Dr. Billy Kristanto serta Stephen Tong. Untuk keperluan rekaman, JSO menggunakan peralatan yang khusus untuk merekam orkestra simfoni dan selalu melibatkan tenaga ahli dari luar yang terbiasa merekam pertunjukan orkestra simfoni. Hal ini dilakukan untuk menghasilkan rekaman yang berkualitas baik. Hasil dari rekaman ini untuk keperluan dokumentasi internal dan kadang juga dibagikan gratis kepada penonton.

Proses dalam penyelenggaraan pertunjukan JSO ini berjalan sangat efisien dibandingkan dengan kelompok orkestra yang lain. Dengan keseluruhan anggota musisi yang profesional, kelompok ini hanya memerlukan waktu latihan selama 3 hari. Ini dimulai dengan pemilihan repertoar musik untuk membuat program konser beberapa minggu sebelum hari penentuan jadwal konser. Setelah itu pihak manajemen JSO akan menghubungi setiap musisi melalui email untuk mengkonfirmasi kesediaannya berpartisipasi di dalam agenda konser. Untuk proses produksi dan eksekusi dalam pertunjukan, manajemen mempercayakan kepada manajer produksi yang membawahkan banyak divisi, meliputi pemasaran, proses produksi saat latihan hingga pertunjukan berlangsung, multimedia, lampu, rekaman, keamanan, tiket hingga line official untuk musisi dan artis.

Jakarta Simfonia Orkestra saat ini telah menjadi ikon musik simfoni di kota Jakarta dan bahkan di Indonesia. Dengan manajemen yang baik serta anggota para musisi yang profesional, JSO telah mampu menunjukkan pertunjukan orkestra simfoni yang sejajar dengan kota-kota besar di dunia. Berbagai surat kabar dan para musisi dunia yang pernah bermain bersama JSO memberikan kesan yang positif (Koran Tempo, 2014).

Stephen Tong selaku pendiri dari kelompok orkestra ini pernah mengatakan kepada penonton dan anggota di saat pertunjukan JSO selesai, bahwa setiap kali JSO menyelenggarakan konser dirinya selalu nombok (rugi) ratusan juta. Persoalan seperti itu sudah berlangsung lama dan menjadi kebiasaan JSO, sebab sejak pertunjukan pertama kali diselenggarakan hingga hari ini JSO tidak pernah mencari sponsor. Begitu juga peran dari pemerintah yang tidak pernah memberikan subsidi bagi penyelenggaraan pertunjukan JSO. Hal ini terlihat dari buku acara atau booklet yang tidak pernah memperlihatkan sponsor, donatur, dan juga media partner.

Mungkin hal ini tidak menjadi persoalan bagi Stephen Tong, namun seringkali yang menjadi kesedihannya adalah ketika para penonton yang lama-kelamaan mulai sepi akan minatnya dalam menyaksikan konser JSO. Hal ini terlihat dari banyaknya kursi penonton 
yang kosong saat pertunjukan konser. Tentu saja JSO sudah memiliki cara tersendiri dalam mengelola keberlanjutan orkestra simfoni ini, namun jika persoalan tersebut terus-menerus menjadi kendala diperlukan langkah untuk mengatasi persoalan tersebut. Langkah yang paling utama adalah mengevaluasi strategi pemasaran yang dilakukan oleh JSO selama ini dan menganalisisnya dengan analisis SWOT untuk mengetahui faktor internal dan eksternal dalam menentukan strategi pemasaran yang tepat untuk keberlanjutan JSO.

\section{Pemasaran}

Kotler (2009), mengemukakan bahwa pemasaran adalah suatu proses sosial yang di dalam individu dan kelompok mendapatkan apa yang mereka butuhkan dan inginkan dengan menciptakan, menawarkan, dan secara bebas mempertukarkan produk yang bernilai dengan pihak lain. Dari definisi tersebut, dapat ditarik kesimpulan bahwa pemasaran merupakan usaha terpadu untuk menggabungkan rencana-rencana strategis yang diarahkan pada usaha pemuas kebutuhan dan keinginan konsumen untuk memperoleh keuntungan yang diharapkan melalui proses pertukaran atau transaksi. Kegiatan pemasaran di dalam perusahaan harus memberikan kepuasan kepada konsumen bila perusahaan itu ingin mendapatkan tanggapan yang baik dari konsumen. Perusahaan juga harus secara penuh bertanggung jawab terhadap kepuasan konsumen terhadap produk yang ditawarkan tersebut. Dengan demikian, segala aktivitas perusahaan harus diarahkan untuk dapat memuaskan konsumen yang pada akhirnya bertujuan untuk memperoleh keuntungan. Bauran pemasaran atau disebut juga dengan marketing mix merupakan salah satu konsep utama dalam pemasaran modern. Pada sisi lainnya terdapat unsur penyesuaian dalam bauran pemasaran dimana para produsen tersebut menyesuikan elemen-elemen bauran pemasaran untuk masing-masing pasar sasaran. Kotler dan Keller (2011) mengemukakan bahwa bauran pemasaran adalah kumpulan alat pemasaran yang taktis dan terkendali yang dipadukan oleh perusahaan untuk menghasilkan respon yang diinginkannya di pasar sasaran. Dan pada tahap selanjutnya mengklasifikasikan alat pemasaran menjadi empat elemen yang disebut "The $4 P$ 's” yaitu: produk (product), harga (price), tempat (place), dan promosi (promotion).

Pemasaran dalam suatu perusahaan menghasilkan kepuasan pelanggan serta kesejahteraan konsumen dalam jangka panjang sebagai kunci untuk mendapatkan keuntungan. Strategi pemasaran adalah upaya dalam pengambilan keputusan mengenai biaya pemasaran, bauran pemasaran, harga produk, kondisi produk, dan alokasi pemasaran (Kotler and Keller, 2009). Strategi pemasaran merupakan langkah yang dilakukan oleh perusahaan manufaktur ataupun perusahaan jasa dalam upaya memenangkan persaingan dalam situasi yang kompetitif yang di hadapai oleh perusahaan. 


\section{Pemasaran Jakarta Simfonia Orchestra}

Pada dasarnya JSO tidak memiliki program yang benar-benar dilakukan secara sungguh-sungguh untuk memasarkan pertunjukannya. Apa yang dilakukannya cenderung kepada intuisi menurut kemampuan masing-masing orang yang bekerja selama ini. Hal ini dikarenakan memang tidak ada manajer pemasaran yang memang fokus terhadap pemasaran pertunjukan (wawancara Baharudin, 13 April 2017). Cara bekerja di dalam tim ini adalah saling membantu diantara yang lain, misalnya jika ada divisi lain yang tidak memiliki beban kerja yang lebih, mereka akan membantu divisi yang lain jika dibutuhkan. Pada akhirnya, selain tim manajemen yang bekerja secara sukarela, JSO melibatkan orang-orang yang ada dalam komunitasnya untuk menyebarkan informasi dan mempromosikan program pertunjukan JSO yang akan berlangsung.

Produk yang ditawarkan oleh JSO adalah jenis musik klasik. Baharudin mengungkapkan kenapa JSO memilih jenis musik ini dikarenakan musik klasik memiliki efek positif terhadap intelenjensi seseorang (wawancara, 13 April 2017). Program yang dimainkan di setiap pertunjukannya meliputi karya-karya untuk instrumen solo seperti konserto, musik simfoni, dan overture dari komposer abad ke 17 hingga abad 20, dan beberapa aria dengan paduan suara. JSO tidak mengikuti selera pasar dalam membuat program musik yang akan dimainkan, orkestra ini lebih banyak membuat program berdasarkan idealismenya dalam mengedukasi. Namun akhir-akhir ini biarpun masih tetap idealis dalam membuat program musik, JSO akan tetap mempertimbangkan faktor penonton dalam membuat program musik.

Kualitas dari pertunjukan JSO ini sangat bagus, sebab JSO melibatkan musisi-musisi klasik profesional dalam setiap pertunjukannya. Program yang disajikan sangat berbobot hingga membuat orkestra ini yang paling konsisten dalam pertunjukan musik klasik sampai hari ini. Wawancara dengan Harianto tanggal 13 April 2017 mengungkapkan bahwa "saya rasa semua orkes ingin konsisten, tapi semuanya bergantung pada budget, tapi saya lihat yang bisa bertahan setiap bulan adalah JSO, itu sampai sebulan sekali mengadakan pertunjukan musik klasik". Hal inilah yang membuat JSO menjadi populer dan menjadikannya barometer pertunjukan musik klasik di Indonesia saat ini dan membuat para musisi yang tergabung di dalamnya juga merasa bangga.

JSO memiliki nilai tambah dibanding dengan kelompok orkestra lain yang tidak memiliki gedung konser sendiri. Aula Simfonia Jakarta adalah tempat pertunjukan musik klasik terbaik yang ada di Indonesia saat ini dengan kapasitas 1.300 kursi, seperti diungkapkan oleh Addie MS dalam wawancara tanggal 14 April 2017, "orkes simfoni bisa tampil tanpa sound system itu seideal-idealnya gedung itu cuma Aula Simfonia Jakarta". Di tempat itulah JSO berlatih dan mengadakan konser. Dengan interior yang bagus perpaduan antara kayu dan marmer menjadikan akustik yang ada di gedung konser ini terasa hangat. Perlu digarisbawahi bahwa akustik yang ada di tempat konser ini adalah yang terbaik keempat di dunia, hal ini dibuktikan dari pernyataan para musisi dunia yang pernah mengadakan konser di tempat ini. Haryanto juga mengungkapkan bahwa kualitas gedung sangat berpengaruh terhadap kenyamanan dan kepuasan pemain dalam menyajikan pertunjukan musik (wawancara 13 April 2017). Akustik yang bagus inilah yang membuat 
para penonton dapat menikmati setiap detail nada yang dimainkan oleh para musisi di atas panggung dengan jelas. Dengan fasilitas yang memadai seperti tempat duduk yang nyaman, sistem pendingin udara yang baik, toilet yang bersih, dan tempat parkir yang luas menjadikan tempat konser ini nyaman bagi penonton. Tidak hanya itu, JSO juga menyediakan petugas keamanan serta petugas kesehatan yang selalu sigap dan siap untuk melayani penonton yang hadir di tempat pertunjukan JSO. Priatna juga mengungkapkan bahwa "kita harus cukup puas dengan gedung pertunjukan yang dimiliki oleh JSO saat ini, meskipun ada beberapa catatan diantaranya adalah tempat yang terlalu jauh bagi para penonton musik klasik yang tinggal di daerah Jakarta Selatan dan harga sewa yang terlalu mahal" (wawancara 20 April 2017).

Harga tiket yang ditawarkan oleh JSO bervariatif, dari harga Rp. 150.000,00 (seratus lima puluh ribu rupiah) untuk kelas pelajar hingga $\mathrm{Rp}$ 1.500.000,00 (satu juta lima ratus ribu rupiah) untuk kelas VVIP. Harga yang ditawarkan disesuaikan berdasarkan posisi tempat duduk, dimana posisi tempat duduk itu sangat berpengaruh terhadap suara yang akan didengarkan dan juga penglihatan dari penonton terhadap musisi yang bermain di atas panggung. Harga pertunjukan JSO ini juga relatif sama dengan pertunjukan orkestra lain yang sejenis. Hal ini diungkapkan oleh Haryanto bahwa "harga tiket dari setiap pertunjukan kelompok orkestra di Jakarta relatif sama tergantung event yang diadakan" (wawancara 13 April 2017). Faktor harga tidak pernah menjadi persaingan bagi JSO maupun kelompok orkestra yang lain ketika ketika menjual tiket. Perlu diketahui bahwa tiket pertunjukan JSO hanya mampu menutup 30 persen dari biaya pertunjukan JSO itu pun jika tiket terjual pertunjukan semua.

Promosi yang dilakukan oleh JSO dilakukan dengan mengoptimalkan peran media sosial terutama di dalam komunitas gereja (wawancara Baharudin, 13 April 2017). Ada beberapa yang menggunakan surat elektronik untuk memberikan informasi. Hal ini disebabkan adanya permintaan dari penonton yang sering menghadiri untuk mendapatkan informasi lebih cepat. Media promosi seperti poster dan selebaran informasi tentang JSO biasanya dititipkan di tempat gereja, sekolah, atau perguruan tinggi yang memiliki jurusan musik. Ada beberapa baliho yang dipasang di salah satu jalan utama di Jakarta Utara dikarenakan ada salah satu dari komunitas gereja yang ingin membantu dalam mempromosikan pertunjukan JSO. Namun menurut Baharudin, promosi yang dilakukan selama ini lebih efisien menggunakan media social dan lebih banyak dari mulut ke mulut sebagian besar dari komunitas gereja (wawancara 13 April 2017).

Berbeda dengan Baharudin, Husin mengungkapkan bahwa dari banyaknya penonton yang hadir, hampir 70 persen ada peran Stephen Tong dalam mempromosikan pertunjukan JSO (wawancara 16 April 2017). Selain dari kalangan jemaat gereja, ada penonton dari kalangan musik. Hal ini diungkapkan oleh Haryanto "setiap kali ada solois terkenal dan dipimpin oleh Yahya Ling selalu banyak yang hadir dari kalangan musik klasik”. 


\section{Hasil Kuesioner Penonton JSO}

\begin{tabular}{|c|c|c|c|}
\hline No & Variabel & Indikator & Jumlah \\
\hline \multirow[t]{2}{*}{1} & \multirow[t]{2}{*}{ Jenis kelamin } & Laki-laki & 42 \\
\hline & & Perempuan & 58 \\
\hline \multirow[t]{5}{*}{2} & \multirow[t]{5}{*}{ Usia } & $<20$ tahun & 16 \\
\hline & & $21-30$ tahun & 62 \\
\hline & & $31-40$ tahun & 7 \\
\hline & & $41-50$ tahun & 6 \\
\hline & & $>50$ tahun & 9 \\
\hline \multirow[t]{5}{*}{3} & \multirow[t]{5}{*}{ Pendidikan Terakhir } & SD & - \\
\hline & & SMP & 2 \\
\hline & & SMA & 15 \\
\hline & & $\mathrm{D} 1 / \mathrm{D} 2 / \mathrm{D} 3$ & 7 \\
\hline & & $\mathrm{S} 1 / \mathrm{S} 2 / \mathrm{S} 3$ & 76 \\
\hline \multirow[t]{5}{*}{4} & \multirow[t]{5}{*}{ Pekerjaan } & Pelajar & 29 \\
\hline & & PNS & 2 \\
\hline & & Karyawan & 33 \\
\hline & & Wirausaha & 14 \\
\hline & & Profesi lainya & 22 \\
\hline \multirow[t]{5}{*}{5} & \multirow[t]{5}{*}{ Penghasilan rata-rata } & $<\mathrm{Rp} 3.500 .000$ & 34 \\
\hline & & Rp 3.501.000 - Rp 7.000.000 & 22 \\
\hline & & Rp 7.001.000 - Rp 10.500.000 & 16 \\
\hline & & Rp 10.501.000 - Rp 14.000.000 & 7 \\
\hline & & $>\mathrm{Rp} 14.001 .000$ & 21 \\
\hline \multirow[t]{2}{*}{6} & \multirow[t]{2}{*}{ Status pernikahan } & Belum menikah & 79 \\
\hline & & Sudah menikah & 21 \\
\hline
\end{tabular}

Sumber: Hasil kuesioner penonton JSO

\section{Penilaian Penonton Terhadap Pertunjukan JSO}

Hasil berikut adalah hasil dari survei terhadap 100 responden penonton JSO yang ketika menonton pertunjukan pada tanggal 8 April dan 23 Mei 2017 di Aula Simfonia Jakarta. Penilaian penonton terhadap pertunjukan JSO terdiri dari 4 variabel, yaitu produk, tempat, harga, dan promosi. Hasil olah data tersebut dapat dilihat pada tabel di bawah ini.

\begin{tabular}{|l|l|l|l|l|l|l|}
\hline No & Variabel & Mean & Std. deviation & Min & Max & Sum \\
\hline 1 & Produk & 2,79 & 0,403 & 2.00 & 3.00 & 279 \\
\hline 2 & Harga & 2,70 & 0,460 & 2.00 & 3.00 & 270 \\
\hline 3 & Tempat & 2,95 & 0,219 & 2.00 & 3.00 & 295 \\
\hline 4 & Promosi & 2,28 & 0,636 & 1.00 & 3.00 & 228 \\
\hline
\end{tabular}

Sumber: hasil olah data 2017 kuesioner penontonton JSO 
Berdasarkan hasil penelitian, terdapat 79 responden (79\%) memberikan penilaian yang baik terhadap variabel produk dilihat dari merek, kemasan, dan kualitas produk. Ini menggambarkan bahwa nama JSO sudah populer sebagai kelompok orkestra yang fokus terhadap pertunjukan musik klasik. Banyak dari penonton yang dari golongan pelajar dan penonton pemula yang menyaksikan pertunjukan JSO yang tadinya hanya ingin tahu tentang pertunjukan JSO, saat ini banyak yang menjadi penggemar yang selalu menunggu pertunjukan JSO dengan program yang ingin dibawakannya.

Berdasarkan hasil penelitian, terdapat 70 responden (70\%) memberikan penilaian baik terhadap variabel harga dilihat dari tiket pertunjukan JSO yang ditawarkan begitu beragam, terjangkau dan sesuai dengan kebutuhan penonton. Penonton dari golongan pelajar menilai harga yang ditawarkan untuk harga tiket terendah pun dinilai terlalu mahal. Hal ini sudah dipikirkan oleh manajemen JSO dengan memberikan diskon harga untuk pembelian lebih awal dan membuat kelas harga tiket pertunjukan menurut kemampuan dari segmen pasar penonton JSO.

Berdasarkan hasil penelitian, terdapat 95 responden (95\%) pertunjukan JSO memberikan penilian yang sangat baik bagi tempat pertunjukan dilihat dari variabel kenyamanan, keamanan dan akses yang strategis. Sebanyak 95 persen penonton merasa puas dengan fasilitas dan akustik yang ada di gedung pertunjukan JSO. Hal ini yang membuat JSO memiliki nilai lebih dibanding kelompok orkestra yang lain yang tidak memiliki gedung pertunjukan sendiri yang memiliki kualitas terbaik dan didesain khusus untuk pertunjukan musik klasik.

Penonton memberikan penilian yang beragam untuk promosi pertunjukan JSO. Berdasarkan hasil penelitian, terdapat 38 responden (38\%) memberikan penilaian baik, 52 responden (52\%) memberikan nilai cukup, dan terdapat 10 responden (10\%) memberikan nilai tidak baik. Hal ini bisa dilihat dari variabel promosi lewat media sosial, iklan dan informasi pertunjukan dari kolega para penonton JSO. Tak dapat dimungkiri bahwa kebanyakan penonton JSO adalah para jemaat GRII yang banyak mendapatkan informasi dari komunitas gereja dan juga promosi dari Stephen Tong itu sendiri.

\section{Analisis SWOT}

Analisis SWOT ini dilakukan dengan tiga tahapan untuk memperoleh beberapa alternatif strategi pengembangan pemasaran pertunjukan JSO. Untuk keperluan analisis SWOT diperlukan responden yang berkaitan langsung dengan JSO dan memiliki pengaruh dalam menentukan keputusan strategis terhadap terhadap tata kelola JSO, diantaranya adalah Baharudin sebagai kepala produksi JSO, Collen sebagai ketua divisi pemasaran JSO serta Rebbeca Tong selaku konduktor JSO. Dari hasil data kualititatif dan kuanitatif peneliti menyimpulkan dalam beberapa faktor internal dan eksternal sebagai berikut:

Faktor internal dalam pemasaran pertunjukan JSO adalah terdiri dari:

1. Kekuatan: Nama Jakarta Simfonia Orchestra sudah terkenal, memiliki gedung konser pertunjukan terbaik dan tempat latihan sendiri, memiliki mitra yang kuat dari jemaat gereja, memiliki anggota musisi profesional dan mitra musisi klasik 
internasional, memiliki fasilitas dan perlengkapan penunjang pertunjukan orkestra simfoni yang lengkap seperti peralatan rekam, audio, visual serta bank repertoar musik yang lengkap.

2. Kelemahan: Masih mengandalkan sosok figur dalam kepemimpinan, tingginya biaya produksi dalam pertunjukan JSO, struktur manajemen yang bekerja secara sukarela, sedikitnya penonton di luar komunitas Gereja Reformed Injil Indonesia.

Faktor eksternal dari pemasaran pertunjukan JSO terdiri dari:

1. Peluang: Menjadi kelompok orkestra simfoni terbaik di Indonesia, menyelenggarakan pertunjukan musik klasik secara rutin, bertambahnya jumlah

Matrix IE Pemasaran JSO

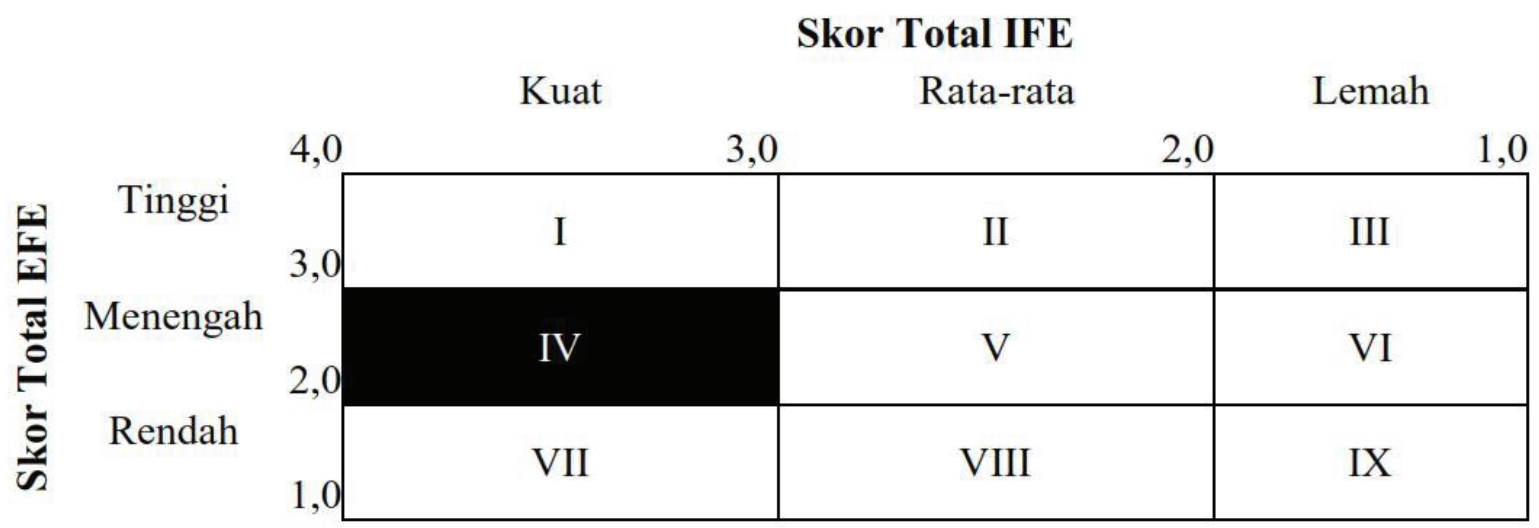

penggemar musik klasik, belum adanya kelompok orkestra lain yang konsisten dengan pertunjukan musik klasik di Jakarta.

2. Ancaman: kelompok orkestra lain yang juga menggunakan musisi yang sama dengan Jakarta Simfonia Orchestra, kurangnya perhatian dari pemerintah kota Jakarta, tidak adanya sponsor dalam pembiayaan pertunjukan JSO yang berkelanjutan, hadirnya kelompok orkestra yang berorientasi pada selera pasar.

\section{Hasil Analisis}

Hasil dari perhitungan nilai bobot yang diisi oleh ke tiga key person, diperoleh hasil IFE sebesar 3,04 dan EFE sebesar 2,75. Angka tersebut selanjutnya dapat menggambarkan posisi pemasaran Jakarta Simfonia Orchestra melalui Matrix IE.

Posisi pemasaran Jakarta Simfonia Orchestra melalui Matrix IE menunjukkan grow and build (tumbuh dan berkembang) karena berada pada posisi IV dan strategi yang diambil oleh manajemen dalam posisi ini biasanya tidak merubah strategi yang selama ini dilakukan demi tercapainya stabilitas yang lebih baik. Strategi umum yang dipakai adalah strategi intensif seperti penetrasi pasar yang sudah ada saat ini, pengembangan pangsa pasar baru, dan pengembangan produk.

Tahap selanjutnya adalah melakukan pencocokan melalui kuadran analisis SWOT. Untuk itu diperlukan bobot skor dari faktor internal dan bobot skor dari faktor eksternal. Bobot skor faktor internal diperoleh dari bobot skor kekuatan dikurangi kelemahan, sedangkan bobot skor faktor eksternal diperoleh dari peluang dikurangi ancaman. Melalui 


\section{Matrik Kuadran Analisis SWOT Pemasaran JSO}

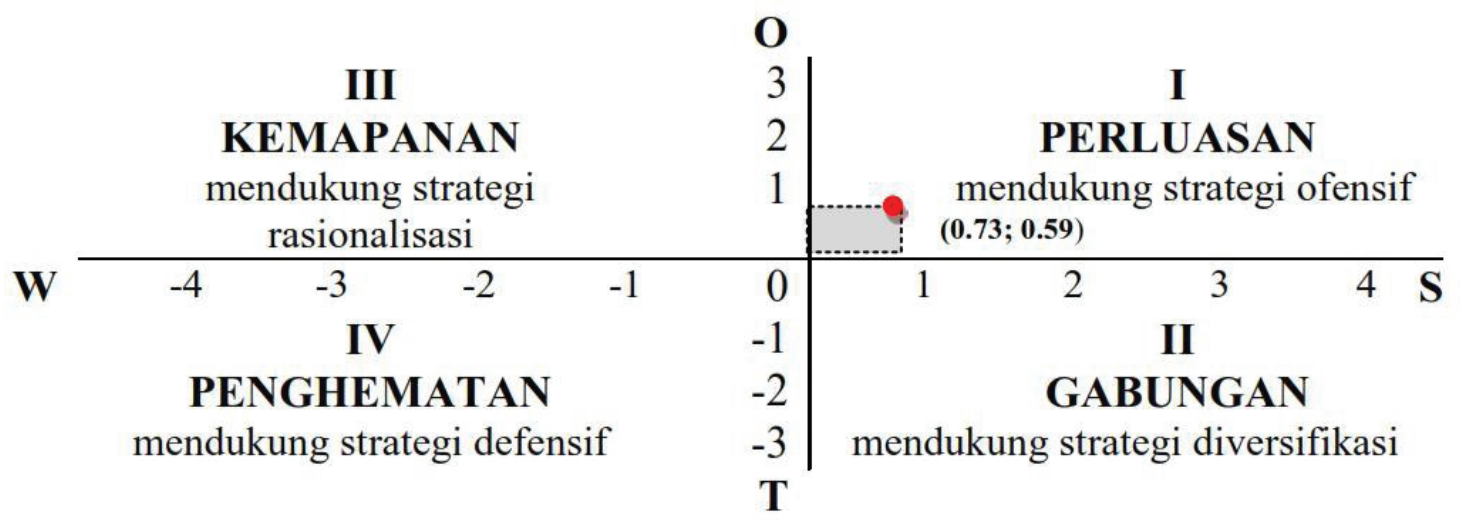

perhitungan tersebut, maka dapat diperoleh kordinat untuk kuadran analisis SWOT yaitu (0.73 - 0.59). Selanjutnya kordinat tersebut dapat digambarkan melalui kuadran analisis SWOT pemasaran Jakarta Simfonia Orchestra sebagai berikut.

Hasil analilis SWOT pemasaran pertunjukan Jakarata Simfonia Orchesta masuk pada kuadran I, ini adalah situasi yang menguntungkan bagi JSO dan strategi yang digunakan dalam kondisi ini adalah mendukung kebijakan menyerang yang agresif. Suwarsono (2008:292) menjelaskan pilihan alternatif bagi perusahaan dalam menentukan strategi pertumbuhan dengan cara konsentrasi, perluasan pasar, pengembangan produk, integrasi horizontal, integrasi vertical, diversivikasi konsentrik, dan diversifikasi konglomerasi. Namun untuk pemasaran JSO saat ini peneliti akan memberikan pilihan-pilihan yang sesuai sebagai berikut:

a) Penetrasi pasar yang sudah ada

Meningkatkan jumlah penonton saat ini dengan melakukan promosi yang lebih giat seperti memberikan lebih banyak potongan harga tiket pertunjukan bagi pelanggan tetap JSO dari kalangan jemaat gereja. Hal ini dilandasi dari hasil wawancara dengan Husin yang menyatakan "banyaknya penonton yang hadir, hampir 70 persen ada peran Stephen Tong dalam mempromosikan pertunjukan JSO" (wawancara 16 April 2017). Hal ini dikuatkan juga dari pernyataan Baharudin yang menyatakan "promosi yang dilakukan selama ini lebih efisien menggunakan media sosial dan lebih banyak dari mulut ke mulut sebagian besar dari komnitas gereja" (wawancara 13 April 2017).

b) Pengembangan pasar yang ada saat ini

Pengembangan pasar dilakukan dengan cara menggiatkan promosi di luar pasar JSO saat ini untuk menarik lebih banyak penonton dari kalangan pelaku dan pecinta musik klasik dengan lebih sering menghadirkan solois terkenal dan dirigen Yahya Ling. Strategi ini dilandasi dari pernyataan dalam wawancara dengan Haryanto 13 April 2017 yang menyatakan "setiap kali ada solois terkenal dan di pimpin oleh Yahya Ling selalu banyak yang hadir dari kalangan musik klasik". Bahkan mereka ada yang dari luar kota mau datang ketika kita memiliki program yang bagus serta artis solo terkenal (Husin, wawancara 16 April 2017). Memberikan workshop ke beberapa sekolah yang memiliki perhatian terhadap pendidikan musik klasik akan memudahkan JSO dalam mempromosikan program yang akan dimainkan dan kegiatan pengembangan pasar yang lain dapat dilakukan dengan cara memberikan diskon 
harga yang lebih besar untuk pelajar dan calon penonton yang ingin membeli tiket untuk lebih dari 3 kali pertunjukan.

c) Pengembangan produk

Pengembangan produk tidak perlu dilakukan secara signifikan, sebab JSO sudah memosisikan diri sebagai kelompok orkestra yang fokus terhadap musik klasik. Pengembangan produk yang mungkin bisa dilakukan oleh JSO adalah dengan menjual merchandise seperti DVD, CD, kaos dan pernak-pernik lainya tentang JSO. Selain itu JSO juga dapat menjual jasa sebagai event organizer dalam setiap produksi pertunjukan orkestra yang menggunakan gedung konser ASJ, serta menyediakan jasa penyewaan partitur ataupun perlengkapan pertunjukan orkestra seperti timpani, alat perkusi, dan standpart.

d) Intregrasi vertikal (depan/belakang)

Intregrasi vertikal dilakukan dengan cara mengurangi biaya produksi dengan membuat lebih efisien pengeluaran di setiap divisi. Memetakan segmen pasar untuk mengoptimalkan strategi promosi yang tepat.

\section{Kesimpulan}

1. Posisi pemasaran pertunjukan Jakarta Simfonia Orchestra melalui Matrik IE menunjukan built and grow (bina dan tumbuh) karena berada pada posisi IV. Strategi umum yang dipakai adalah intensif (penetrasi pasar, pengembangan pasar dan pengembangan produk)

2. Berdasarkan kuadran analisis SWOT, pemasaran pertunjukan Jakarta Simfonia Orchestra menunjukkan posisinya berada pada kuadran I sehingga diperlukan pemilihan strategi berupa penggunaan setiap kekuatan untuk menghadapi ancaman dengan membangun pasar, penetrasi pasar, pengembangan produk, integrasi vertikal (depan/belakang), dan integrasi horizontal.

\section{Implikasi Manajerial}

1. Karena berada pada posisi IV yang berarti growth strategy, JSO perlu melakukan strategi intensif di antaranya adalah:

a. Penetrasi pasar. Pasar JSO saat ini adalah sebagian besar dari kalangan jemaat gereja, maka dari itu JSO perlu memberikan perhatian yang lebih dalam meningkatkan jumlah penonton saat ini dengan melakukan promosi yang lebih giat dan memberikan lebih banyak potongan harga tiket pertunjukan bagi pelanggan tetap JSO dari kalangan jemaat gereja.

b. Pengembangan pasar. Pengembangan pasar dilakukan untuk meningkatkan pangsa pasar yang ada dengan memasarkan kepada segmen pasar pecinta music klasik dan para pelajar dengan memilih repertoar musik klasik yang berbobot serta sering mendatangkan musisi dan kondakter internasional untuk bergabung dalam pertunjukan JSO. Untuk kalangan pelajar JSO bisa melakukannya dengan memberikan potongan harga yang lebih besar serta sesekali memberikan apresisai 
dan worksop secara cuma-Cuma untuk memberikan rangsangan terhadap selera dan minat mereka kepada musik klasik.

c. Pengembangan produk dapat dilakukan oleh JSO dengan menjual merchandise seperti DVD, CD, kaos, gantungan kunci, tas, dan pernak-pernik lainya tentang JSO. Selain itu JSO juga dapat menjual jasa sebagai event organizer dalam setiap produksi pertunjukan orkestra yang menggunakan gedung konser ASJ, serta menyediakan jasa penyewaan partitur ataupun perlengkapan pertunjukan orkestra seperti timpani, alat perkusi, dan standpart.

2. Analisis SWOT JSO berada pada kuadran I yang menggambarkan situasi JSO saat ini sangat baik karena memiliki kekuatan yang dapat dimanfaatkan untuk meraih peluang yang ada, untuk itu diperlukan strategi yang agresif. Langkah-langkah yang dilakukan seperti halnya pada no. 1 poin a, b, c, dan integrasi vertikal dengan membuat Jakarta Youth Simfoni Orchestra untuk juga berkontribusi dalam mensuplai anggota musisi JSO. Selain itu JSO juga dapat membuat lebih efisien setiap pengeluaran di dalam semua divisi yang berkaitan dengan pertunjukan JSO.

\section{Kepustakaan}

Askegaard, 2011. Marketing, the Performing Arts and Social Change: Beyond the Legitimacy Crisis. Consumption Markets \& Culture, 3:1, 1-25.

Arnold, Denis, 1979. Giovanni Gabrieli and the Music of the Venetian High Renaissance. London: Oxford University Press. ISBN 0-19-315247-9

Besana, Angela. 2012. Alternative Resources: Revenue Diversification In The Not-ForProfit Usa Symphony Orchestra, The Journal Of Arts Management, Law, And Society, 42: 79-89, 2012.

Bonita M. Kolb, 2001. The Decline of The Subscriber Base: A Study Of The Philharmonia Orchestra Audience. International Journal Of Arts Management Volume 3, No. 2.

Crawford, garry dkk. 2014. An Orchestral Audience: Classical Music And Continued Patterns of Distinction, Jurnal Cultural Sociology, 8(4), pp. 483-500. Th. 2014.

David, Fred R. 2006. Manajemen Strategi: Konsep. Edisi 10 Jakarta: Salemba Empat.

Joohee, Hong, 2014. Data Envelopment Analysis in the Strategic Management of Youth Orkestra. The Journal of Arts Management, Law, and Society. Seattle University, Seattle, Washington.

Kotler, Philip, 2000. Manajemen Pemasaran, Alih Bahasa Benjamin Molan dan Hendra Teguh, Edisi Milenium. Jakarta: PT. Macanan Jaya Cemerlang.

Kotler \& Keller, 2009. Manajemen Pemasaran, edisi kedua belas jilid 1. Alih bahasa oleh Benyamin Molan dan Hendra Teguh. Jakarta: PT. Macanan Jaya Cemerlang. .2009. Manajemen Pemasaran, edisi ketiga belas, Alih bahasa oleh

Benyamin Molan dan Hendra Teguh. Jakarta: PT. Macanan Jaya Cemerlang.

Lovelock, Kristhoper \& Wirtz, Jochen, 2011. Servis Marketing, People, Technology, Strategi, Sevent Edition. Pearson.

Moghaddam, Farshid Movaghar \& Faroughi, Amir. 2012. The Influence of Marketing Strategy Element on Market Share Firm, Internasional Journal of Fundamental Psychology \& Sosial Sciences (IJFPSS), Volume 2 No.1. (ISSN: 2231-9484).

Nazir, M. 2005. Metode Penelitian. Ghalia Indonesia, Jakarta. 
Pompe, Tamburri dan Munn. 2011. Factors that Influence Programming Decisions of US Symphony Orchestras. J Cult Econ 35:167-184.

Rangkuti, Fredi. 2015. Analisis SWOT: Teknik Membedah Kasus Bisnis (cara perhitungan bobot, rating dan OCAI). Jakarta: PT. Gramedia Pustaka Utama.

Reksohadiprojo, Sukanto. 2009. Manajemen Starategi: BPFE. Yogyakarta.

Schultz, Kimberly B. 2009. How Symphony Orkestras In Chicago, ST. Louis, And Peoria Use Sosial Media Tools To Connect With The Public. Thesis: Fine Arts of Webster University.

Sekaran and Bougie. 2013. Research Methods for Business. India: Library of Congress. Sitowati, Inggit. 2010. Relevansi Selera Musik dan Kelas Sosial. Jurnal Musik UKSW, Vol. 2, No. 1.

Stanley, Sadie. 2004. "Symphony" dalam Stanley Sadie (ed). The New Grove Dictionary of Music and Musicians vol. 24 (London: Macmillan Publishers Limited), 812.

Sugiono. 2015. Metode Penelitian dan Pengembangan. Bandung: ALFABETA.

Susilo, Edhi. 2012. Orkes Simfoni Jakarta dan Musik Klasik di Indonesia. Yogyakarta: Badan Penerbit ISI.

\section{Sumber Internet}

Aulasimfonia.com

https://id.pinterest.com/pin/471048442253780185/, diakses pada tanggal 16 Mei 2017.

http://musicalprom.com/2017/01/22/menyambut-tahun-baru-bersama-jakarta-simfoniaorchestra/, diakses pada tanggal 20 Februari 2017.

https://photowikimapia.org, diakses pada tanggal 2 Juni 2017.

\section{Sumber Wawancara}

Baharudin Suryadi, Manajer produksi Jakarta Simfonia Orchestra. W awancara, 22 Desember 2016 di Aula Simfonia Jakarta.

Husin Kamil, Direktur RMCI yang menaungi pengelolaan Jakarta Simfonia Orcehtra.

Hariyanto, Musisi yang bergabung dengan Jakarata Simfonia Orchestra dan juga kelompok orkestra yang lain.

Fafan Isfadiar, Musisi yang bergabung dengan Jakarata Simfonia Orchestra dan juga kelompok orkestra yang lain.

Avip Priatna, Konduktor Jakarta Concert Orchestra.

Addie MS, Konduktor Twilite Orchestra. 